\title{
WITHDRAWAL FROM MULTI-EMPLOYER BARGAINING- RECONSIDERING RETAIL ASSOCIATES
}

Large-scale federal regulation of labor-management relations began with congressional passage, in 1935, of the National Labor Relations Act. ${ }^{1}$ As is often the case with such major legislation, the act was not a labor code, but rather a matrix for future development-to be filled in by judicial interpretation, administrative decision and further statutory regulation consistent with the lessons of experience. ${ }^{2}$

The rules governing collective bargaining between an association of employers and the representatives of their employees constitute one area left for future development. ${ }^{3}$ Section 7 of the Wagner Act expressly guaranteed the right of employees to organize or join a union, and to bargain collectively; ${ }^{4}$ other sections detailed the way in which this right could be exercised. Section 9(a) provided that the representatives selected by a majority of the employees in a labor unit were to be the exclusive representatives of all the employees in that unit; ${ }^{5}$ and section 9(b) assigned to the National Labor Relations Board the task of determining the employee unit appropriate for collective bargaining, subject to the explicit statutory limitation that the appropriate unit be either the employer unit, the craft unit or a subdivision thereof. ${ }^{6}$

The act did not speak to the appropriateness, for collective bargaining purposes, of an employee unit corresponding in scope to a multi-

149 Stat. 449 (1935), as amended, 29 U.S.C. \$\$141-67 (1964).

2 Cox \& Bor, LABor LAW 122-23 (6th ed. 1965); see Phelps Dodge Corp. v. NLRB, 313 U.S. 177, 194 (1941).

3 The confusing term, "multi-employer" unit, is frequently used by the Board and by the courts to describe the employees in this relationship. The synonymous and better term, "association-wide" unit, is also used though less frequently. This Comment will follow accepted practice and use these terms interchangeably to designate the employee unit, not its bargaining counterpart, the multi-employer association.

4 Employees shall have the right to self-organization, to form, join, or assist labor organizations, to bargain collectively through representatives of their own choosing, and to engage in concerted activities, for the purpose of collective bargaining or other mutual aid or protection.

49 Stat. 452 (1935), as amended, 29 U.S.C. $\$ 157$ (1964).

- Representatives designated or selected for the purposes of collective bargaining by the majority of the employees in a unit appropriate for such purposes, shall be the exclusive representatives of all the employees in such unit for the purposes of collective bargaining in respect to rates of pay, wages, hours of employment, or other conditions of employment . . .

49 Stat. 453 (1935), as amended, 29 U.S.C. $\$ 159$ (a) (1964).

6 The Board shall decide in each case whether, in order to assure to employees the full benefit of their right to self-organization and to collective bargaining, and otherwise to effectuate the policies of this Act, the unit appropriate for the purposes of collective bargaining shall be the employer unit, craft unit, plant unit, or subdivision thereof . . . .

49 Stat. 453 (1935), as amended, 29 U.S.C. $\$ 159$ (b) (1964). 
employer association ${ }^{7}$ - despite the fact that in some industries collective bargaining on such a basis far antedated the act. ${ }^{8}$

Shortly after passage of the act, the Board's allowance of such multi-employer bargaining occasioned, in Shipozeners' Ass' $n,{ }^{9}$ a challenge to NLRB authority to certify as appropriate for bargaining a labor unit comprising all the longshoremen in four Pacific ports. This unit corresponded to an existing employer association for that area. ${ }^{10}$ Forced to resolve the issue with neither congressional nor judicial assistance, the Board found the power necessary to approve such association-wide units by deeming the association to be within the statutory definition of an "employer." The act denominated an employer as "any person acting in the interest of an employer, directly or indirectly." 11 By construing the multi-employer group to be an

7 There was clear awareness of this omission by 1947 when Congress was considering the Labor Management Relations Act (Taft-Hartley Act), 61 Stat. 136 (1947), as amended, 29 U.S.C. $\$ \$ 141-67$ (1964), and a considerable spectrum of opinion as to what action would then be appropriate. The Senate passed a redefinition of the term "employer" as used in the act, S. 1126, 80th Cong., 1st Sess. \$2(2) (1947), the avowed purpose of which was to authorize the Board to continue its practice, see notes 9-13 infra and accompanying text, of certifying association-wide labor units so long as the employers had voluntarily associated themselves. S. REP. No. 105, 80th Cong., 1st Sess. \$2(2) (1947). The House, on the other hand, evidenced concern over the economic power concentrated in such units when they encompassed a large industry and the damaging effect of industry-wide work stoppages. H.R. REP. No. 245, 80th Cong., 1st Sess. §9(f) (1) (1947). The bill reported from committee to the House therefore imposed severe limitations on the size, or alternatively the nature, of multi-employer units. H.R. 3020, 80th Cong., 1st Sess. \& 9(f) (1) (1947). House sentiment was strong enough to defeat a floor attempt to delete this section of the House bill. 93 CoNG. REc. 3570 (1947). The bill reported from the conference committee contained neither provision and leaves, therefore, a difficult question as to the precise intent of a Congress which has consciously refused to act definitively, despite an awareness of the need for legislation.

8 See NLRB v. Truck Drivers Local 449, 353 U.S. 87, 94-95 (1957) (Buffalo Linen); 66 HARv. I. REv. 886 (1953). Thus, one of the first problems faced by the NLRB in administering multi-employer bargaining was when, and under what circumstances, a multi-employer unit should be approved as appropriate. The Board almost immediately isolated the factors it would consider in designating a unit appropriate for collective bargaining and which it soon applied to multi-employer units: 1) the history of labor relations in the industry and between a particular employer and his employees as relates to collective bargaining units; 2) the community of interest or lack of such interest among employees in the matter of qualifications for work, experience, duties, wages, hours and other working conditions; 3 ) the organization of the business of the employer from a functional, physical and geographical viewpoint; and 4) the form which efforts at self-organization among the employees have taken. 1 NLRB ANN. REP. 113 (1936). Although all these factors were considered in the early cases involving certification of multi-employer units, Waterfront Employers Ass'n, 71 N.L.R.B. 80 (1946) ; Shipowners' Ass'n, 7 N.L.R.B. 1002 (1938), the factor of bargaining history seems to have become determinative. 16 NLRB ANN. REP. 102-03 (1951) ; see Bercut Richards Packing Co., 64 N.L.R.B. 133 (1945). 87 N.L.R.B. 1002 (1938).

10 The challenge was presented by the International Longshoremen's Association, A.F.L., with some support by the employers. The coast-wide employer association had a current contract with the Pacific Coast District of the I.L.A. However, the unit was not Board-certified and the agreement negotiated was the modified extension of an earlier arbitration settlement by the National Longshoremen's Board. Union dissatisfaction with the A.F.L. caused a fissure and a majority of the longshoremen on the Pacific Coast, though not in each port, favored withdrawal from the A.F.L. and reaffiliation with the International Longshoremen's and Warehousemen's Union, C.I.O. The I.L.W.U. petitioned the Board for certification as representative for a unit including all the employees in the Pacific Coast ports.

11 Section 2(2), 49 Stat. 450 (1935), as amended, 29 U.S.C. \$152(2) (1964). 
employer, the Board then could exercise its section 9(b) power to certify an "employer" labor unit as appropriate for bargaining. ${ }^{12}$ This construction also subjected the association to the employer's duty, under section $8(5)$ of the act, to bargain with the Board-certified unit or face an unfair labor practice charge. ${ }^{13}$

The Board's finding of authority to certify association-wide units was not tested by the Supreme Court until 1957, when the question was posed by the Board's decision in Buffalo Linen Supply Co. ${ }^{14}$ In that case, the Truck Drivers Union, representing employees in a multiemployer bargaining unit, called a strike against only one member of the employer association. The union thereby threatened to "whipsaw" first one and then possibly the other employers into more favorable settlements. The NLRB ruled that the nonstruck employers had the right to lock out their employees. ${ }^{15}$ The court of appeals reversed, considering the threat of whipsaw no more serious than the threat that a strike would ordinarily pose to an employer who did not belong to an association. ${ }^{16}$ The Supreme Court, however, upheld the Board and found the lockout justified. ${ }^{17}$

The union specifically argued the impropriety of the determination by the Board that an association-wide unit was appropriate, although bargaining had been based on such a unit for over thirteen years. Taking this opportunity to review the development of Board practice and authority, the Supreme Court concluded that Congress intended to approve the continued certification of these larger units. The Court based this conclusion on the rejection of proposals to restrict such units when Congress considered the Taft-Hartley amendments to the National Labor Relations Act. ${ }^{18}$

12 See note 6 supra and accompanying text. This continued to be the Board construction whenever its authority was challenged. Waterfront Employers Ass'n, 71 N.L.R.B. 80, 109-10 (1946); see NLRB v. Lund, 103 F.2d 815, 819 (8th Cir. 1939). The definition of employer was changed slightly by the Taft-Hartley Act to include "any person acting as an agent of an employer, directly or indirectly." Section 2(2), 61 Stat. 137 (1947), 29 U.S.C. \$152(2) (1964). The change was not of such a nature as to affect the Board's derivation of authority from this section. See FrEmIN, THE TAfT-HaRtley ACT ANd Multi-Employer Bargaining 17-19 (1948).

13 "It shall be an unfair labor practice for an employer . . . to refuse to bargain collectively with the representatives of his employees, subject to the provisions of section 9(a)." Section 8(5), 49 Stat. 453 (1935), as amended, 29 U.S.C. \& 158(a) (5) (1964). This section was renumbered $\$ 8(\mathrm{a})(5)$, but not otherwise changed, when the Taft-Hartley Act was passed.

14109 N.L.R.B. 447 (1954).

15 The union in this case had charged the employers with violation of $\S \S 8(a)$ (1) and (3). Section 8(a) (3) makes it an unfair labor practice for an employer by discrimination to encourage or discourage membership in any labor organization. 61 Stat. 140 (1947), as amended, 29 U.S.C. $\$ 158(a)(3)$ (1964). The $\$ 8(a)(1)$ violation was derivative. See note 35 infra. Linen).

16 Truck Drivers Local 449 v. NLRB, 231 F.2d 110 (2d Cir. 1956) (Buffalo

17 NLRB v. Truck Drivers Local 449, 353 U.S. 87 (1957) (Buffalo Linen).

$18 \mathrm{Id}$. at 95-96. Inferring legislative approval from a failure to take specific action is a very unreliable means of determining the meaning of a statute. MISHKIN \& Morris, ON LAW IN Courts $481-98$ (1965). This is particularly the case in view of the legislative history discussed in note 7 supra. 
With the question of the Board's authority thus resolved, the Court went on to discuss the role of the NLRB in the decision of future questions in the multi-employer area. In this regard, the Court stated that Congress 'intended to leave to the Board's specialized judgment the inevitable questions concerning multi-employer bargaining bound to arise in the future." 19 The nature and scope of NLRB discretion granted by Congress in this area was then described:

The ultimate problem is the balancing of the conflicting legitimate interests. The function of striking that balance to effectuate national labor policy is often a difficult and delicate responsibility, which the Congress committed primarily to the National Labor Relations Board, subject to limited judicial review. ${ }^{20}$

This decision, then, clearly sanctioned the multi-employer labor unit, and allowed the Board discretion in dealing with such units as long as a balance was struck between the various conflicting interests likely to present themselves in each case. ${ }^{21}$

While the Court in Buffalo Linen sanctioned the certification of association-wide units and, implicitly, the criteria used by the Board to find such units appropriate, it specifically refused to consider, until properly before it, the correlative question of the conditions under which withdrawal from such units should be allowed. ${ }^{22}$ The Board, however, in the routine of administering multi-employer bargaining, had already developed criteria to control employer withdrawal. These criteria were set forth in summary form in its Twenty-third Annual Report:

In order for withdrawal from multiemployer bargaining to be effective, the withdrawing party must unequivocally indicate at an appropriate time that it desires to abandon such bargaining. ... The decision to withdraw must contemplate a sincere abandonment, with relative permanency, of the multiemployer unit and the embracement of a different course of bargaining on an individual-employer basis. The element of good faith is a necessary requirement in any such decision to withdraw because of the unstabilizing and disrupting effect on multiemployer collective bargaining which would result if such withdrawal were permitted to be lightly made. ${ }^{23}$

The Board's power to restrict withdrawal from multi-employer bargaining derived from the denomination of the association as an

18353 U.S. at 96.

20 Ibid. (Emphasis added.)

21 See NLRB v. Metropolitan Life Ins. Co., 380 U.S. 438 (1965).

22353 U.S. at 94 n.22.

2323 NLRB ANN. REP. 37 (1958). 
"employer" and the consequent imposition on the association of the section 8(a) (5) duty of an employer to bargain with the Boardcertified unit. ${ }^{24}$ In practice, however, employer withdrawal was relatively unrestricted. ${ }^{25}$ Notification of intention to withdraw could easily be made, and the requirement of timeliness did not prevent withdrawal even during negotiation periods. ${ }^{26}$ The Board, however, emphasized the requirement of a sincere abandoning of multi-employer bargaining. An attempt to withdraw temporarily for a reason such as securing a bargaining advantage would be foreclosed by this requirement and that of good faith. ${ }^{27}$

Union withdrawal was considered to be a matter apart from withdrawal by an employer, and was generally allowed only in extraordinary circumstances. ${ }^{28}$ Because the effect of a union withdrawal is to terminate the multi-employer bargaining arrangement, whereas an employer withdrawal will ordinarily only cause a reduction in the size of a unit, disparate treatment cannot be said to be without a reasonable basis. Recent authorities have considered this problem and determined that equality of treatment is preferable, but the Supreme Court has yet to rule on the question. ${ }^{29}$

In 1958, the NLRB chose the case of Retail Associates, Inc. ${ }^{30}$ to restructure prospectively the existing withdrawal requirements by a

24 See notes 11-13 supra and accompanying text.

25 ABA Labor Relations Law Sectron, 1953-59 Proceedings, Report of the Comm. on Development of the LaW UNDER National Labor Relations Act 17 (1959). See 66 HaRv. L. Rev. 886, 889-95 (1953), for a general discussion of both employer and union rights to withdraw at that time.

26 For typical Board decisions allowing withdrawal, over union objections, see Jones \& Anderson Logging Co., 114 N.L.R.B. 1203 (1955) (withdrawal during negotiations of a group of all the employers in a smaller geographical unit from a larger association); W. A. Swanson Logging Co., 111 N.L.R.B. 495 (1955) (complete abandonment of the employer association during negotiations by simultaneous withdrawal of each employer in the association); 20th Century Press, 107 N.L.R.B. 292 (1953) (withdrawal by a single employer during negotiations) ; Moscow Idaho Seed Co., 107 N.L.R.B. 107 (1953) (withdrawal by a single employer, at employees' urging, before negotiations had begun); Stamford Wall Paper, Inc., 92 N.L.R.B. 1173 (1951) (withdrawal by a single employer during the term of an interim contract negotiated by the association after an impasse had been reached).

27 See, e.g., Jahn-Tyler Printing \& Publishing Co., 112 N.L.R.B. 167 (1955). The employer had a history of bargaining with the Typographical Union, but was dissatisfied with the employees being supplied by the union. $\mathrm{He}$ therefore informed the employer association that he might not sign a contract again with the Typographical Union, and lent his support to a petition by the Amalgamated Lithographers, a rival union, for establishment of a single-employer unit. On these facts, the Board found that there was no sincere abandoning of the multi-employer bargaining unit and no intent to pursue labor relations on a single-employer basis, particularly in light of the fact that the employer had not requested similar single-employer units for his typographical or letterpress employees also covered by multi-employer agreements. Withdrawal was therefore disallowed.

28 See, e.g., Continental Baking Co., 99 N.L.R.B. 777 (1952) ; Morand Bros. Beverage Co., 91 N.L.R.B. 409 (1950) ; 66 HARv. L. REv. 886, 889-95 (1953). The requirements for union withdrawal may never have been so clear as those for employer withdrawal. Continental Baking Co., supra at 787 (dissenting opinion).

29 See note 57 infra.

30120 N.L.R.B. 388, ten day temporary restraining order granted on other grounds sub nom. Retail Clerks Ass'n v. Leedom, 43 L.R.R.M. 2004, preliminary injunction denied, 43 L.R.R.M. 2029 (D.D.C. 1958). 
statement of "specific ground rules" for the decision of future cases. The Board stated:

[We] would . . . refuse to permit the withdrawal of an employer or a union from a duly established multiemployer bargaining unit, except upon adequate written notice given prior to the date set by the contract for modification, or to the agreed-upon date to begin the multiemployer negotiations. Where actual bargaining negotiations based on the existing multiemployer unit have begun, we would not permit, except on mutual consent, an abandonment of the unit upon which each side has committed itself to the other, absent unusual circumstances. ${ }^{31}$

The restrictions announced in this rule introduced two major adjustments in the right to withdraw as previously administered. First, the flexible requirements which had governed employer withdrawal were hardened so that any withdrawal during the period of negotiations would be, per se, a violation of section $8(a)(5)$. Thus all inquiry into the motivation or occasion for the action would be eliminated. Second, the union right to withdraw was expanded and put on an exact par with that of the employer.

The first occasion for judicial review of the rule in Retail Associates was presented in NLRB v. Sheridan Creations, Inc. ${ }^{32}$ a case whose factual situation particularly demonstrates the problems inherent in the adoption of a per se rule in the area of withdrawal from multi-employer bargaining. Sheridan attempted to withdraw from his multi-employer bargaining association, a majority, three out of four, of his employees no longer wishing to be represented by the union. ${ }^{33}$ $\mathrm{He}$ also ceased to recognize the union as the representative of his employees, and refused to execute the contract which was ultimately negotiated by the association. ${ }^{34}$ As a result, the union filed unfair

31 Id, at 395 . The absence of any decisions predicated upon the unusual circumstances exception suggests that this proviso may not be particularly meaningful in Board applications of the rule.

32357 F.2d 245 (2d Cir.), petition for cert. filed, 35 U.S.L. WEEK 3175 (U.S. Nov. 4, 1966) (No. 747), affirming 148 N.L.R.B. 1503 (1964).

$33 \mathrm{Had}$ Sheridan been successful in withdrawing, he would have had-with regard to his employees-all the rights and duties of a single employer who had not been a part of such a multi-employer association. Ordinarily, the union would continue to be the certified representative of the employees, and the employer would be obligated to continue to bargain with and recognize the union. This results from the Board presumption of continued majority status. Celanese Corp., 95 N.L.R.B. 664, 671-73 (1951). Obviously, a decertification election would, if the union lost, overcome this presumption. In the period before an election, the employer does not, except for the period of one year following a previous election, commit an unfair labor practice if he refuses to bargain with the union as a result of a good faith doubt of the union's majority status. See NLRB v. Southern Coach \& Body Co., 336 F.2d 214 (5th Cir. 1964), and cases cited therein.

34 Because NLRB unit determinations are not subject to direct judicial review, AFL v. NLRB, 308 U.S. 401 (1940), the proper way to secure review of such deter- 
labor practice charges with the Board, accusing Sheridan of violating sections $8(\mathrm{a})(1)$ and $(5) .^{35}$

On hearing before the trial examiner, it was determined that Sheridan had committed no unfair labor practice. The trial examiner also made a specific factual finding that the withdrawal was in good faith. ${ }^{36}$ Nonetheless, the Board, on appeal, declared "well-settled" ${ }^{37}$ the rule that employer withdrawal during negotiations, absent union consent, was untimely, and ordered the employer to recognize the union as the representative of his employees and to execute the associationnegotiated contract. The NLRB secured enforcement of its order against Sheridan in the Court of Appeals for the Second Circuit. The case thus presents the anomalous situation of an employer and his employees being compelled to accept, as binding between them, a contract negotiated by an association which the employer disavows and a union which his employees oppose.

minations is by a refusal to bargain and then an appeal in the unfair labor practice proceeding. When unfair labor practice charges are incurred for this purpose (seeking review), then unless some violation independent of this is prosecuted, the entire complaint fails if the unit determination is improper. Pittsburgh Plate Glass Co. v. NLRB, 313 U.S. 146 (1941). Sheridan's refusal to execute the association contract is just an extension of the refusal to bargain, and the refusal to recognize the union is similarly the result of honest dotbt of union majority status in the unit Sheridan believes appropriate. An independent unfair labor practice charge would not seem warranted by these actions, and the entire Board case must turn on the propriety of the unit determination.

35 The $\$ 8$ (a) (1) violation is a "derivative" violation. Brief for Respondent, p. 2, NLRB v. Sheridan Creations, Inc., 357 F.2d 245 (2d Cir. 1966). The Board may prosecute the commission of an employer unfair labor practice charging violation of both the specific statutory section and also violation of $\$ 8(a)(1)$, which makes it an unfair labor practice for the employer to interfere with any of his employees' rights as guaranteed by $\$ 7$. Cox \& Bok, LABOR LAw 169 (6th ed. 1965).

36 Sheridan Creations, Inc., 148 N.L.R.B. 1503, 1514 (1964) (trial examiner's decision). A timely attempt by Sheridan to withdraw-made at least three months before the union indicated it wished to begin negotiations on a new contract-was frustrated by erroneous advice from an association officer. NLRB v. Sheridan Creations, Inc., 357 F.2d 245, 249 (2d Cir. 1966) (dissenting opinion).

37 An examination of the cases which the Board cites as authority for prior use of the per se withdrawal rule shows that it was never more than an alternative ground for the decision, and in some cases cited it was not even mentioned. The Kroger Co., 148 N.L.R.B. 569 (1964), was decided on the company's failure to notify either the other members of the employer association, or the union, indicating only that if the contract finally negotiated contained a clause which it found particularly objectionable it would withdraw from the association and refuse to execute the contract. Withdrawal was refused because Kroger showed no clear intent to pursue a different course of bargaining relations. In Ice Cream, Frozen Custard Employees, 145 N.L.R.B. 865 (1964), employer withdrawal was allowed after negotiations had reached an impasse and the union not only consented to the withdrawal, but had urged separate negotiations. The Retail Associates rule specifically excluded cases of mutual consent from its coverage. C \& M Constr. Co., 147 N.L.R.B. 843 (1964), is similarly a case of union acceptance of the withdrawal, the distinguishing factor being lack of explicit acceptance. Union conduct, however, was such as to indicate consent. The Board stated that the controlling law was not in dispute and did not discuss the Retail Associates rule; since the union consented, the per se rule was not applicable. The opinion in Walker Electric Co., 142 N.L.R.B. 1214 (1963), affirms the trial examiner with no mention of the rule. The trial examiner, although mentioning the rule, found that secrecy and lack of good faith were determinative where the employer had failed to inform the union of his withdrawal and simultaneously attempted to aid another local in the reorganization of his plant. None of these Board decisions has been 
It is probable that Sheridan's withdrawal would have been allowed under the case-by-case approach which preceded the per se rule of Retail Associates. ${ }^{38}$ Nevertheless, hardship for a particular party or inequities in a single case do not necessarily indicate that a per se approach is inappropriate. A per se rule, like any NLRB regulation or requirement, may be adopted by the Board on a proper showing in the initial case that a balance of conflicting interests was struck to effectuate national labor policy. ${ }^{39}$ This balance, of course, must be fully explicated in the first opinion in order to make judicial review feasible. ${ }^{40}$

In Retail Associates the Board did not engage in this required balancing of interests and explication, but rather said only that "the timing of an attempted withdrawal from a multiemployer unit ... is an important lever of control in the sound discretion of the Board to ensure stability of such bargaining relationships," 41 and that the rules rest on the "existing principles and policies under the Act," the fundamental purpose of which the Board found to be the maintainance of bargaining stability. ${ }^{42}$

Not until its brief to the Second Circuit in Sheridan did the Board attempt to explain the reason for the rule formulated in Retail Associates. $^{43}$ In its brief, the Board reasoned that labor peace, which is clearly an objective of national labor policy, ${ }^{44}$ stems in part from stable bargaining relationships and uniform group contracts. It then argued that allowing withdrawal during negotiations would permit a party to the negotiations to use withdrawal as a means to secure better

judicially reviewed; however, an earlier decision in the same Kroger dispute, The Kroger Co., 141 N.L.R.B. 564 (1963), was reviewed by the District of Columbia Circuit and, ironically, occasioned a considerable discussion of the greater propriety of a case-by-case approach to multi-employer problems. Retail Clerks Union v. NLRB, 330 F.2d 210 (D.C. Cir. 1964).

38 In a case with facts almost identical to Sheridan, Moscow Idaho Seed Co., 107 N.L.R.B. 107 (1953), the Board found a single-employer unit appropriate. A distinguishing factor is that although the union had sent notice of its desire to negotiate a new contract, bargaining had not already begun.

39 See Phelps Dodge Corp. v. NLRB, 313 U.S. 177 (1941); cf. NLRB v. Truck Drivers Local 449, 353 U.S. 87, 96 (1957) ; SEC v. Chenery Corp., 332 U.S. 194 (1947). In Retail Clerks Union v. NLRB, 330 F.2d 210 (D.C. Cir. 1964), however, the court expounded upon the superiority of a case-by-case balancing approach over employment of per se rules in Board determinations of multi-employer unit questions.

40 See NLRB v. Metropolitan Life Ins. Co., 380 U.S. 438 (1965) ; Phelps Dodge Corp. v. NLRB, supra note 39 ; cf. SEC v. Chenery Corp., supra note 39 . This is also the general mandate of the Administrative Procedure Act, which requires that "all decisions . . include a statement of-(A) findings and conclusions, and the reasons or basis thereof, and all the material issues of fact, law, or discretion presented on the record; and (B) the appropriate rule, order, sanction, relief, or denial thereof." 5 U.S.C. $\$ 557$ (b) (Supp. - ).

41 Retail Associates, Inc., 120 N.L.R.B. 388, 395 (1958).

42 Id. at 393-95.

43 Such a post hoc rationalization does not satisfy the requirements of balancing and explication. See NLRB v. Metropolitan Life Ins. Co., 380 U.S. 438, 442-44 (1965) ; cf. Burlington Truck Lines, Inc. v. United States, 371 U.S. 156, 167-69 (1962).

44 See 61 Stat. 136 (1947), 29 U.S.C. \$141 (1964). 
contract terms, thus destroying the unit's stability and uniformity. ${ }^{45}$ This reasoning seems subject to an attack predicated upon the language of the Supreme Court in the recent case of NLRB v. Brown. ${ }^{40}$ In Brown, which involved a lockout situation, the Court stated that "the Act does not constitute the Board as an 'arbiter of the sort of economic weapons the parties can use in seeking to gain acceptance of their bargaining demands." "47 It is by no means inconceivable that the Court would find that withdrawal, like a lockout, is a weapon to be used freely by the parties in bargaining.

Assuming however that the Board is not precluded by Brown from considering the effect that withdrawal has on bargaining stability, bargaining stability seems to be only one of many factors which the Board should have considered in Retail Associates. Many of these other factors are highlighted by Sheridan. One precept of national labor policy so clear as to be axiomatic is that employees should be accorded the greatest possible freedom to organize according to their own desires and common interests. Section 1 of the Wagner Act made it the declared policy of the United States to protect "the exercise by workers of full freedom of association, self-organization, and designation of representatives of their own choosing, for the purpose of negotiating the terms and conditions of their employment or other mutual aid or protection." 48 The Taft-Hartley Act, far from changing this policy, reenforced it by (1) guaranteeing employees the right to refrain from organization, and (2) limiting the Board's section 9(b) discretion in the determination of appropriateness of labor units where previous Board certifications had compromised the separate interests of distinct smaller groups in order to form larger bargaining units. ${ }^{49}$

45 Brief for Petitioner, pp. 15-16, NLRB v. Sheridan Creations, Inc., 357 F.2d 245 (2d Cir. 1966).

46380 U.S. 278 (1965).

47 Id. at 283, citing NLRB v. Insurance Agents' Union, 361 U.S. 477, 497 (1960); accord, American Ship Bldg. Co. v. NLRB, 380 U.S. 300 (1965). The Brown decision in particular constitutes somewhat of a sequel to Buffalo Linen. The facts are substantially similar, except that in Brozen the struck employer exercised his right to hire replacements, and the nonstruck employers, who had locked out their employees, as Buffalo Linen allowed, also replaced the regular workers in order to remain competitive. The Board found, on complaint by the union, that this was an unfair labor practice since it gave the employers too much bargaining strength. Brown Food Store, 137 N.I.R.B. 73 (1962) (by implication), enforcement denied sub nom. NLRB v. Brown, 319 F.2d 7 (10th Cir. 1963). The Supreme Court, however, affirming the court of appeals, concluded that this was a situation in which a legitimate employer economic interest conflicted with a legitimate employee interest and that the Board, in balancing these interests, could not consider relative bargaining power as a factor to be weighed. 380 U.S. at 286 . The Court apparently felt that consideration of this factor would remove the Board's determination from the realm of effecting labor policy and place it in that of making major policy decisions. The latter was a function which the Court felt properly belonged to Congress.

48 Section 1, 49 Stat. 449 (1935), as amended, 29 U.S.C. \$151 (1964).

49 To the enumeration of employee rights in $\$ 7$ of the Wagner Act, quoted in note 4 supra, was added "the right to refrain from any or all of such concerted activities." 61 Stat. 140 (1947), 29 U.S.C. $\$ 157$ (1964). 'The Board power of certification reenacted in $\$ 9$ (b), 61 Stat. 143 (1947), 29 U.S.C. $\$ 159$ (b) (1964), was limited by the proviso: 
The employer, too, may have a legitimate interest to be considered in the balance. $\mathrm{He}$, of course, is concerned with efficient and economic management of his enterprise, and decisions made in accordance with that interest would seem deserving of consideration. ${ }^{\mathbf{5 0}}$ Moreover, the employer also has an interest in the maintenance of his employees' right to free choice of representatives, since employee morale and even production could be threatened when employees are expected to participate in strikes which they do not support, or are fined for failure to participate. ${ }^{51}$ The employer's view of his own interest may justify his pressing for protection of his own and his employees' rights. ${ }^{52}$

The Board unfortunately discussed none of these interests ${ }^{53}$ and considered only the factor of bargaining stability in its enunciation of the per se withdrawal restriction of Retail Associates, and in its application of that rule in Sheridan. In view of a reviewing court's obligation to refuse to uphold an administrative rule where there has been a failure by the agency either to engage in the proper balancing or to explicate the balance upon which the rule was adopted, ${ }^{54}$ it would seem that the Second Circuit should have remanded Sheridan to allow the Board to apply the appropriate standards. Unfortunately, the court devoted only one sentence to consideration of the NLRB's duty to balance interests and explain its decision. The court concluded tersely that "the Board's rule . . . seems to us logical." 55

What the Sheridan case makes clear is that the NLRB needs to reconsider the per se withdrawal restriction announced in Retail Associates in light of the many legitimate interests which constitute

[T] he Board shall not (1) decide that any unit is appropriate for such purposes if such unit includes both professional employees and employees who are not professional employees unless a majority of such professional employees vote for inclusion in such unit; or (2) decide that any craft unit is inappropriate for such purposes on the ground that a different unit has been established by a prior Board determination, unless a majority of the employees in the proposed craft unit vote against separate representation or (3) decide that any unit is appropriate for such purposes if it includes, together with other employees, any individual employed as a guard ...

These limitations grew from a general congressional concern that the Board was too frequently including in a larger unit employees who formed a distinguishable group appropriate for a smaller unit more in accordance with their wishes, and were designed to be a statutory prohibition of the worst Board abuses in this area. H.R. CoNF. REP. No. 510, 80th Cong., 1st Sess. § 9(b) (2) (1947); Fremin, The Taft-HartLey ACT AND MULTI-EMPLOY BR BARGAINING 20-21 (1948).

50 See NLRB v. Brown, 380 U.S. 278 (1965); American Ship Bldg. Co. v. NLRB, 380 U.S. 300 (1965).

51 See generally Comment, $8(b)(1)(A)$ Limitations Upon the Right of a Union To Fine Its Members, 115 U. PA. L. REv. 47 (1966).

$52 C f$. ABA Labor Retations Law Section, 1953-59 Proceedings, Report of the CoMar. on DevelopMent of the Law Under National Labor Relations Act 45 (1959).

53 Administrative convenience and the certainty afforded by a per se rule are also factors which might perhaps be considered by the Board. However, these factors should not alone be determinative. Phelps Dodge Corp. v. NLRB, 313 U.S. 177, 197-200 (1941).

54 See notes $39-40$ supra and accompanying text.

65357 F.2d at 247. 
national labor policy. The consideration of stability needs to be probed in greater depth. It should be balanced against the employee interest in maximum freedom to be represented as he chooses, and the employer right to operate his business-including his labor relationsin his own best interest.

There is no lack of alternatives open to the Board on reconsideration of the Retail Associates rule. It is conceivable that a proper balance might convince the Board and, on review, a court that the per se restriction was the wisest rule. Or the Board could recant somewhat and hold the bar to withdrawal applicable only in situations where withdrawal would in fact cause a disruptive change in the bargaining unit or in negotiations. The problems raised by cases like Sheridan might be avoided by giving meaning to the "unusual circumstances" exception to the per se rule which was articulated in Retail Associates but which has never been applied. Another possibility is that the Board, after the proper balancing, might favor a return to a case-by-case determination similar to the law prior to Retail Associates. Finally, it is possible that the Board would consider itself bound by the language of $N L R B v$. Brozen quoted above, ${ }^{56}$ and consequently refuse to strike down even withdrawals motivated by the desire to gain a bargaining advantage. The very number and diversity of alternative approaches to the problem of withdrawing from multiemployer bargaining constitute a strong argument for a thorough and thoughtful balance by the Board of the conflicting interests involved. Only when such a balance has been struck, with an eye toward effecting national labor policy, will this interstice in the National Labor Relations Act be properly and definitively filled. ${ }^{57}$

\section{See text accompanying note 47 supra.}

57 Recent court of appeals decisions involving related questions have not materially altered the status of Sheridan or the need for Supreme Court review. In Universal Insulation Corp. v. NLRB, 361 F.2d 406 (6th Cir. 1966) (employer withdrawal not allowed), the court relied primarily on NLRB v. Jeffries Banknote Co., 281 F.2d 893 (9th Cir. 1960) (employer withdrawal not allowed), in which the court excepted the question faced by the Second Circuit in Sheridan. The Ninth Circuit opinion based its decision on the employer's failure to give unequivocal notice of intent to withdraw and specifically reserved the case of adequate notice. Id. at 896 n.2. In Publishers' Ass'n v. NLRB, 364 F.2d 293 (2d Cir. 1966), the question of urion withdrawal after timely notice was considered. The holding in favor of withdrawal, while consistent with the Retail Associates rule, turns on the issue whether union withdrawal should be governed by the same rules as those regulating employer withdrawal. The problem in Sheridan was not this, but whether withdrawal during negotiations should be prohibited per se absent consent of the other party. 